\title{
COMPRESSIVE STRENGTH OF CONCRETE WITH FLY ASH, NANOSILICA AND RECYCLED AGGREGATE
}

\author{
Arshdeep Singh ${ }^{1}$, Roshan Lal ${ }^{2}$, Pankaj Bavoria ${ }^{3}$, Abhinav Saklani $^{4}$ \\ ${ }^{1}$ Assistant Professor, Civil Engineering Department, PEC University of Technology, Chandigarh, India \\ ${ }^{2}$ Associate Professor, Civil Engineering Department, PEC University of Technology, Chandigarh, India \\ ${ }^{3}$ Post Graduate Student, Civil Engineering Department, PEC University of Technology, Chandigarh, India \\ ${ }^{4}$ Post Graduate Student, Civil Engineering Department, PEC University of Technology, Chandigarh, India
}

\begin{abstract}
In this study, concrete mix was prepared using recycled aggregates (RA) which were retrieved from demolished concrete blocks. Pozzolanic materials like fly ash (FA) and nanosilica (NS) were used as partial replacement of cement by weight in varying percentages i.e. 10\%, 20\% 30\% and 2\%, 3\%, 4\% respectively. The experimental work was focused on investigating the effect of nanosilica and fly ash on fresh properties and compressive strength of recycled aggregate concrete (RAC). To examine the fresh properties of concrete, slump test was performed for workability requirements. It was observed from experimental results that with the increase in percentage of recycled aggregates in concrete, compressive strength decreases but workability was not affected up to $50 \%$ variation of recycled aggregates. Results showed that with the addition of nanosilica compressive strength of concrete was increased but workability was decreased with the increase in percentage of nanosilica. The use of fly ash in addition to nanosilica $(30 \% \mathrm{RA}+3 \% \mathrm{NS}+10 \% \mathrm{Fly}$ Ash) improved both the workability and compressive strength of recycled aggregate concrete (RAC).
\end{abstract}

Keywords: Compressive strength, Recycled aggregates (RA), Nanosilica (NS), Fly Ash (FA), Recycled aggregate concrete $(R A C)$.

\section{INTRODUCTION}

Concrete is a construction material which is extremely used worldwide in every kind of construction purposes. Preparation of concrete involves use of natural resources like sand, stone aggregates, water etc. The present boom in day by day growing buildings is leading to excessive use of concrete, thereby resulting in depletion of natural resources such as sand and stone aggregates. In fact, there is acute shortage of natural stone aggregates and this problem is faced by many countries in the world [1]. On the other hand, due to demolition of old structures, it is very difficult sometimes to find a dumping place for such a huge amount of waste concrete. To overcome such kind of situation it may be a better approach to retrieve aggregates from demolished material and use it again in concrete in any possible manner. This process may help to preserve the natural aggregates to some extent and also in the reduction of cost of material. Practically, the quality of concrete may decline due to the low density, high water absorption and weak bond of recycled aggregates [2]. But this issue can be resolved using various kinds of admixtures which may improve the microstructure of concrete and hence will lead to improved quality of recycled aggregate concrete.

Recently nanotechnology is being used in many applications of engineering and technology and has received increasing attention in building materials [3]. Nano materials have high surface area with highly reactive sites on their surface. Siliceous materials like nanosilica reacts with calcium hydroxide at very early age to form calcium silicate hydrate gel and improves the microstructure of concrete at the interface of aggregates and cement paste [4]. The use of nanosilica in concrete can also protect the structure from sulphate attack and alkali silica reaction. With the use of nanosilica, concrete becomes more compact and its resistance to water permeability increases [5].

Recycled aggregates have substantial effect on compressive strength of concrete. In recent studies, it has been noticed that up to $10-20 \%$ replacement of natural coarse aggregates with recycled aggregates has no significant effect on the compressive strength of concrete [6]. But, with the increase in the percentage of recycled aggregates, compressive strength of prepared concrete decreases. Significant improvement in compressive strength has also been reported with the addition of silica in cement mixes owing to increase in pozzolanic activity [7]. The use of nanosilica decreases the leaching of calcium in cement paste and produces a more stable calcium silicate hydrate gel [8]. Keeping all these facts in mind we designed the present study in which nanosilica has been taken to investigate its effect on the properties of recycled aggregate concrete. In addition to nanosilica, effect of fly ash on the strength characteristics of recycled aggregate concrete is also investigated. 


\section{OBJECTIVES}

The objective of this research work is to explore the feasibility and effect of replacement of natural aggregate with recycled aggregate using cement replacement techniques at Nano level. This will help in conserving the natural resources and keeping ecological balance to fulfill present demand of construction material in infrastructure development sector which is increasing at alarming rate. Therefore it is required to enhance the utility of waste material and at the same time minimize the demand for natural aggregates to meet the future demand.

Based on the need of the further investigation to explore the ever expanding field of recycled aggregate concrete blended with Nano silica and Fly ash following objectives has been identified:

- To investigate the effect of replacement of recycled aggregates with natural aggregates in varying percentage.

- To investigate the effect of replacement of cement by fly ash on recycled aggregate concrete.

- To investigate the effect of replacement of cement by fly ash and nanosilica on fresh properties of recycled aggregate concrete.

- To investigate the effect of nanosilica and fly ash on compressive strength of concrete.

\section{MATERIALS USED}

\subsection{Nanosilica}

Nanosilica is highly pozzolanic material. It contains very fine particles approximately 1000 times smaller than the cement particles. In the present study colloidal form of nanosilica has been used i.e. nanosilica in dispersion with water in 40:60 ratio (40\% Nanosilica). Nanosilica used in the study was manufactured by Bee Chems HO: E-5, Panki Industrial Area, Site-1, Kanpur-208022, UP India. Nanosilica is being manufactured for a range of $15 \%$ to $40 \%$ Active Nano content with particle size in the range of 5-40 nm. Sample CemSyn XFX has been used in the present study, the one with active nano content of $40-41.50 \%$ and $\mathrm{pH}$ value of 9.4-10.0 and specific gravity of 1.2-1.22. CemSyn is a series of silica based binders /fillers used in the cementing and concreting operations to impart different properties to the resultant compositions.

\subsection{Fly ash}

Fly ash remains were obtained from Guru Nanak Dev Thermal Plant, Bathinda, Punjab, India. To evaluate the properties of fly ash, the properties described by research center tests led by Central Soil and Material Research Station, New Delhi and CBRI, Roorkee were utilized. Physical properties of fly ash as shown in table 1 confirm to specifications of IS: 3812(P-1)-2003. Fly ash of class F was used. The three principle constituents of fly ash are $\mathrm{SiO}_{2}(25$ to $60 \%), \mathrm{Al}_{2} \mathrm{O}_{3}\left(10\right.$ to $30 \%$ ), and $\mathrm{Fe}_{2} \mathrm{O}_{3}(5$ to $25 \%$ ). In ASTM Class $\mathrm{F}$ the sum of $\mathrm{SiO}_{2}, \mathrm{AI}_{2} \mathrm{O}_{\mathrm{a}}$ and $\mathrm{Fe}_{2} \mathrm{O}_{3}$ is $70 \%$ or greater. This class normally has calcium oxide less than $10 \%$ [12].
Table-1: Physical Properties of Fly Ash.

\begin{tabular}{|c|c|c|c|}
\hline S.No. & Item & Unit & Test Result \\
\hline 1. & $\begin{array}{c}\text { Fineness } \\
\text { Blaine's } \\
\text { Specific Surface }\end{array}$ & $\mathrm{m}^{2} / \mathrm{kg}$ & 400.6 \\
\hline 2. & Specific Gravity & - & 2.03 \\
\hline 3. & $\begin{array}{l}\text { Lime reactivity } \\
\text { average } \\
\text { compressive } \\
\text { strength }\end{array}$ & $\mathrm{N} / \mathrm{mm}^{2}$ & 4.8 \\
\hline 4. & $\begin{array}{c}\text { Soundness by } \\
\text { autoclave }\end{array}$ & $\%$ & 0.22 \\
\hline 5. & $\begin{array}{l}\text { Compressive } \\
\text { strength at } 28 \\
\text { days }\end{array}$ & $\mathrm{N} / \mathrm{mm}^{2}$ & 85.0 \\
\hline 6. & $\begin{array}{l}\text { Sieve Analysis } \\
45 \text { micron }\end{array}$ & $\%$ retained & 30 \\
\hline
\end{tabular}

\subsection{Aggregates}

Aggregate is the component of a composite material that resists compressive stress and provides bulk to the composite material. For efficient filling, aggregate should be much smaller than the finished item, but have a wide variety of sizes. Locally available aggregates were used which were obtained from pathankot. Both $20 \mathrm{~mm}$ and $10 \mathrm{~mm}$ aggregates were available locally. Specific gravity of coarse aggregate was found to be 2.65 and water absorption was $0.48 \%$. Sand of Zone II was used in this study. Specific gravity of fine aggregates was found to be 2.62 [13]. Recycled coarse aggregates of $10 \mathrm{~mm}$ and down were retrieved from demolished concrete blocks. Specific gravity of recycled aggregates was found to be 2.45 and water absorption was $1.31 \%$

\subsection{Cement}

Ordinary Portland cement (OPC) of 43 Grade from a solitary bunch was utilized for all the cement blends. Cement used was fresh and without any lumps with uniformity in its shading. The cement was tested for its consistency, initial and final setting time, specific gravity and compressive strength for 7 and 28 days as per IS: $8112-$ 2013 [11] as depicted in table 2.

\subsection{Superplasticizer}

The superplasticizer for enhancing workability and to reduce water cement ratio was used. It was sulphonated naphthalene formaldehyde with specific gravity 1.2.

Table-2: Properties of Ordinary Portland cement.

\begin{tabular}{|l|l|l|l|}
\hline S.No. & Item & Test Result & $\begin{array}{l}\text { As per IS- } \\
8112-2013\end{array}$ \\
\hline 1. & $\begin{array}{l}\text { Normal } \\
\text { consistency (\%) }\end{array}$ & 29 & - \\
\hline 2. & Specific Gravity & 3.12 & 3.15 \\
\hline 3. & $\begin{array}{l}\text { Initial setting } \\
\text { time (minute) }\end{array}$ & 58 & $>30$ \\
\hline
\end{tabular}




\begin{tabular}{|l|l|l|l|}
\hline 4. & $\begin{array}{l}\text { Final setting } \\
\text { time (minute) }\end{array}$ & 316 & $<600$ \\
\hline 5. & $\begin{array}{l}\text { Compressive } \\
\text { strength } \\
\left(\mathrm{N} / \mathrm{mm}^{2}\right)\end{array}$ & & \\
7 days & 36.57 & $>33$ \\
& 28 days & 46.95 & $>43$ \\
\hline
\end{tabular}

\section{EXPERIMENTAL PROCEDURE}

The experimental program was proposed to investigate the effect of replacement of cement by nanosilica and fly ash on compressive strength of concrete containing recycled aggregates. In the first part of the study the natural aggregates are proposed to be replaced by coarse aggregates retrieved from construction demolition waste in varying percentages i.e $20 \%, 30 \%, 40 \%$ and $50 \%$ to produce recycled aggregate concrete. In the second phase of study, the effect of replacement of cement by nanosilica and fly ash in varying percentages on the compressive strength of concrete was investigated. Mix proportion and quantity of ingredients used is shown in table 3 .

Table-3: Mix design quantities and Proportion ratio.

\begin{tabular}{|l|l|l|l|l|}
\hline S.No. & $\begin{array}{l}\text { Water } \\
\left(\mathbf{K g} / \mathbf{m}^{3}\right. \\
)\end{array}$ & $\begin{array}{l}\text { Cement } \\
\left(\mathbf{K g} / \mathbf{m}^{\mathbf{3}}\right)\end{array}$ & $\begin{array}{l}\text { Fine } \\
\text { Aggregate } \\
\mathbf{s}\left(\mathbf{K g} / \mathbf{m}^{3}\right)\end{array}$ & $\begin{array}{l}\text { Coarse } \\
\text { Aggregate } \\
\mathbf{s}\left(\mathbf{K g} / \mathbf{m}^{3}\right)\end{array}$ \\
\hline Quantity & 163 & 362 & 694 & 1208 \\
\hline $\begin{array}{l}\text { Mix } \\
\text { Proportion }\end{array}$ & 0.45 & 1 & 1.917 & 3.34 \\
\hline
\end{tabular}

\subsection{Testing Procedure}

The cube molds of size $150 \mathrm{~mm}$ x $150 \mathrm{~mm}$ x $150 \mathrm{~mm}$ were casted. The test samples were stamped and expelled from the mold and submerged in clean water for proper curing. A $3000 \mathrm{kN}$ limit Compression Testing Machine (CTM) was utilized to lead the test. The sample was put between the steel plates of CTM and complete load was connected at the rate of $5.20 \mathrm{kN} / \mathrm{s}$ and the failure load in $\mathrm{kN}$ was observed on the monitor screen [9]. Slump test was conducted as per codal provisions to investigate the workability of concrete [10].

\subsection{Specimen Detail and Results}

Each specimen was given different notations to avoid the confusion or mixing of samples. Experimental program consists of casting and testing of 309 concrete cubes of standard size of $150 \mathrm{~mm} \times 150 \mathrm{~mm}$ x $150 \mathrm{~mm}$. Total 11 sets of mixes were prepared out of which one set consist of standard mix with natural aggregates and remaining 10 sets of recycled aggregates were having 3 mixes each and each mix having 9 cubes for 7 day, 28 day \& 56 day compressive strength respectively. Natural aggregates were replaced by recycled aggregates in varying percentages i.e. $20 \%, 30 \%$, $40 \%$ and $50 \%$. Further, $30 \%$ and $40 \%$ variation was selected for investigation on effect of nanosilica. Recycled aggregates used in the present study were of size $10 \mathrm{~mm}$ and down only. Variation of nanosilica and fly ash was done by
$2 \%, 3 \%, 4 \%$ and $10 \%, 20 \%, 30 \%$ respectively. Details of each mix are shown in table 4.

\section{DISCUSSION OF RESULTS}

The workability of cement concrete was evaluated using slump test. In case of standard mix, the slump was $75 \mathrm{~mm}$ but in case of mixes with $2 \%$ nanosilica the slump was 70 $\mathrm{mm}$, in case of $3 \%$ nanosilica the slump was $62 \mathrm{~mm}$ and in case of $4 \%$ nanosilica slump was $50 \mathrm{~mm}$. However mixes with $2 \%$ and $3 \%$ nanosilica of the weight of cement held good for workability as required for concreting but mix with $4 \%$ nanosilica did not achieve required workability which means it becomes very difficult to use it for construction purposes. Recycled aggregates did not change the slump value of the standard mix when added in different percentages which means recycled aggregates does not affect the workability of concrete. Moreover, with the use of fly ash the workability of recycled aggregate concrete was improved.

It was observed from the compression test results of cubes that compressive strength decreases as the percentage variation of recycled aggregates was increased. There was minor decrease in compressive strength for $20 \%$ replacement of natural aggregates and it showed a decreasing pattern as shown in chart 1 up to $50 \%$ replacement.

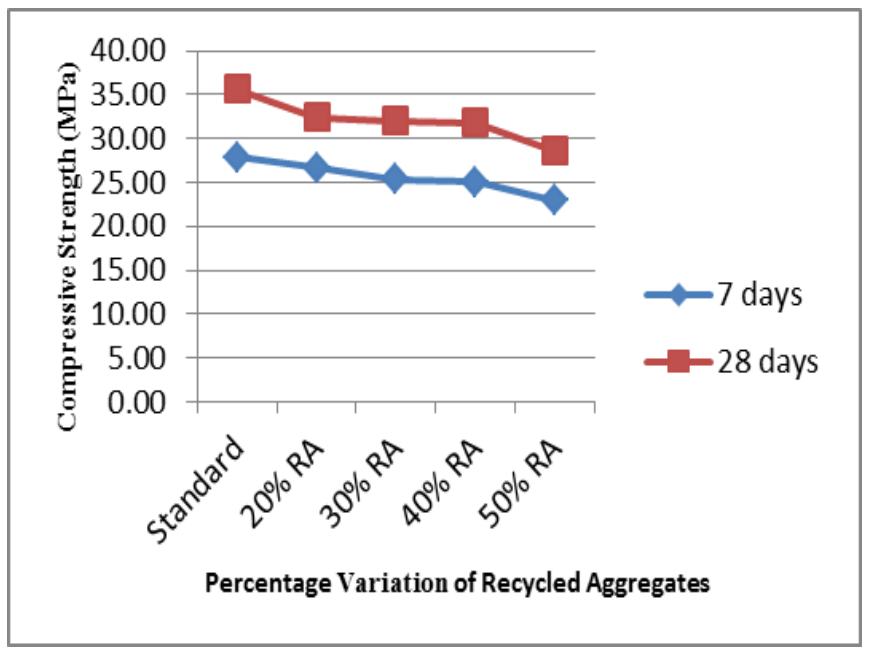

Chart-1: Compressive strength variation of concrete incorporating different percentages of recycled aggregates.

Table-4: Detail of each specimen showing variation in percentage change and compressive strength results.

\begin{tabular}{|c|c|c|c|c|c|c|c|c|}
\hline \multirow{2}{*}{$\begin{array}{l}\mathrm{S} . \\
\mathrm{N} \\
\mathrm{O}\end{array}$} & & \multirow[t]{2}{*}{ Mix } & \multirow[t]{2}{*}{$\begin{array}{l}\% \\
\mathrm{RA}\end{array}$} & \multirow{2}{*}{$\begin{array}{l}\% \\
\mathrm{~N} \\
\mathrm{~S}\end{array}$} & \multirow{2}{*}{$\begin{array}{l}\% \\
\text { Fly } \\
\text { Ash }\end{array}$} & \multicolumn{3}{|c|}{$\begin{array}{l}\text { Compressive strength } \\
\left(\mathrm{N} / \mathrm{mm}^{2}\right)\end{array}$} \\
\hline & & & & & & 7 day & $\begin{array}{l}28 \\
\text { day }\end{array}$ & $\begin{array}{l}56 \\
\text { day }\end{array}$ \\
\hline 1 & $\begin{array}{l}\mathrm{M} \\
0\end{array}$ & M0 & 0 & 0 & 0 & 27.91 & 35.60 & 51.36 \\
\hline \multirow[t]{3}{*}{2} & \multirow{3}{*}{$\begin{array}{l}\mathrm{M} \\
1\end{array}$} & M1 & 30 & 2 & 0 & 28.10 & 35.47 & 51.61 \\
\hline & & M1' & 30 & 3 & 0 & 29.75 & 36.07 & 51.83 \\
\hline & & M1' & 30 & 4 & 0 & 30.49 & 34.88 & 47.94 \\
\hline
\end{tabular}




\begin{tabular}{|c|c|c|c|c|c|c|c|c|}
\hline \multirow[t]{3}{*}{3} & \multirow{3}{*}{$\begin{array}{l}M \\
2\end{array}$} & $\mathrm{M} 2^{\prime}$ & 40 & 2 & 0 & 27.41 & 34.34 & 50.97 \\
\hline & & M2 & 40 & 3 & 0 & 29.31 & 34.91 & 50.78 \\
\hline & & M2 & 40 & 4 & 0 & 29.02 & 33.83 & 46.54 \\
\hline \multirow[t]{3}{*}{4} & \multirow{3}{*}{$\begin{array}{l}M \\
3\end{array}$} & M3 & 30 & 0 & 10 & 24.06 & 32.07 & 46.83 \\
\hline & & M3 & 30 & 0 & 20 & 22.61 & 30.36 & 45.04 \\
\hline & & M3 & 30 & 0 & 30 & 22.41 & 29.74 & 43.60 \\
\hline \multirow[t]{3}{*}{5} & \multirow{3}{*}{$\begin{array}{l}M \\
4\end{array}$} & M4 & 30 & 2 & 10 & 26.99 & 34.00 & 49.36 \\
\hline & & M4 & 30 & 2 & 20 & 27.67 & 32.96 & 47.93 \\
\hline & & M4 & 30 & 2 & 30 & 23.77 & 28.55 & 46.87 \\
\hline \multirow[t]{3}{*}{6} & \multirow{3}{*}{$\begin{array}{l}M \\
5\end{array}$} & M5 & 30 & 3 & 10 & 27.61 & 34.90 & 49.97 \\
\hline & & M5 & 30 & 3 & 20 & 27.04 & 33.27 & 48.10 \\
\hline & & M5 & 30 & 3 & 30 & 26.24 & 30.92 & 46.86 \\
\hline \multirow[t]{3}{*}{7} & \multirow{3}{*}{$\begin{array}{l}M \\
6\end{array}$} & M6 & 30 & 4 & 10 & 27.99 & 33.40 & 47.07 \\
\hline & & M6 & 30 & 4 & 20 & 26.82 & 31.78 & 45.21 \\
\hline & & M6 & 30 & 4 & 30 & 25.86 & 31.26 & 45.56 \\
\hline \multirow[t]{3}{*}{8} & \multirow{3}{*}{$\begin{array}{l}M \\
7\end{array}$} & M7 & 40 & 0 & 10 & 23.86 & 32.10 & 45.66 \\
\hline & & M7 & 40 & 0 & 20 & 22.10 & 30.45 & 44.98 \\
\hline & & $\mathrm{M} 7$ & 40 & 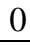 & 30 & 21.50 & 30.21 & 42.86 \\
\hline \multirow[t]{3}{*}{9} & \multirow{3}{*}{$\begin{array}{l}M \\
8\end{array}$} & M8 & 40 & 2 & 10 & 26.63 & 33.04 & 48.70 \\
\hline & & M8 & 40 & 2 & 20 & 26.52 & 31.58 & 47.07 \\
\hline & & M8 & 40 & 2 & 30 & 25.48 & 30.45 & 46.01 \\
\hline \multirow[t]{3}{*}{10} & \multirow{3}{*}{$\mathrm{N}$} & M9 & 40 & 3 & 10 & 27.70 & 33.88 & 48.61 \\
\hline & & M9 & 40 & 3 & 20 & 27.30 & 32.78 & 46.37 \\
\hline & & M9 & 40 & 3 & 30 & 26.01 & 30.84 & 46.07 \\
\hline \multirow[t]{3}{*}{11} & \multirow{3}{*}{$\begin{array}{l}\mathrm{M} \\
10\end{array}$} & M10 & 40 & 4 & 10 & 28.20 & 32.79 & 45.26 \\
\hline & & M10 & 40 & 4 & 20 & 27.23 & 31.45 & 41.26 \\
\hline & & M10 & 40 & 4 & 30 & 26.35 & 29.67 & 38.96 \\
\hline
\end{tabular}

Nanosilica being a fine material improves the hydration process and hence the early age strength of concrete. As shown in chart 2, it was observed that 7 days compressive strength of RAC increases with the variation of nanosilica from $2 \%$ to $4 \%$ and there was a slight decrease in 28 days strength of RAC with $4 \%$ nanosilica. This may be due to the high heat of hydration or less workability of concrete at this percentage variation.

From chart 3 and chart 4 , it can be observed that with the use of fly ash in recycled aggregate concrete, compressive strength of concrete decreases. Fly ash helped in improving the workability of concrete.

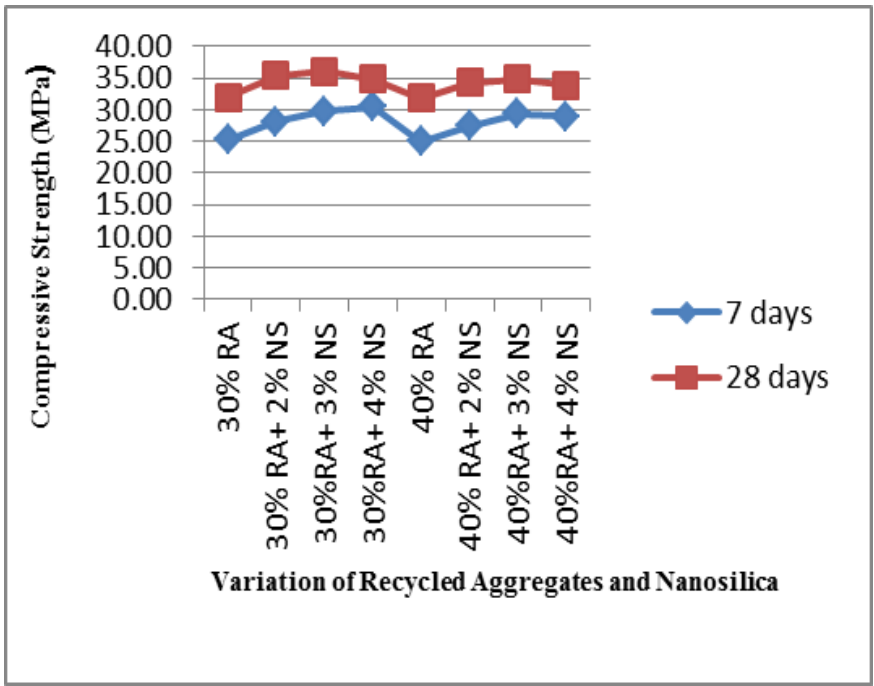

Chart-2: Compressive strength variation of concrete incorporating $30 \%$ and $40 \%$ of recycled aggregates with $2 \%$, $3 \%$ and $4 \%$ of nanosilica.

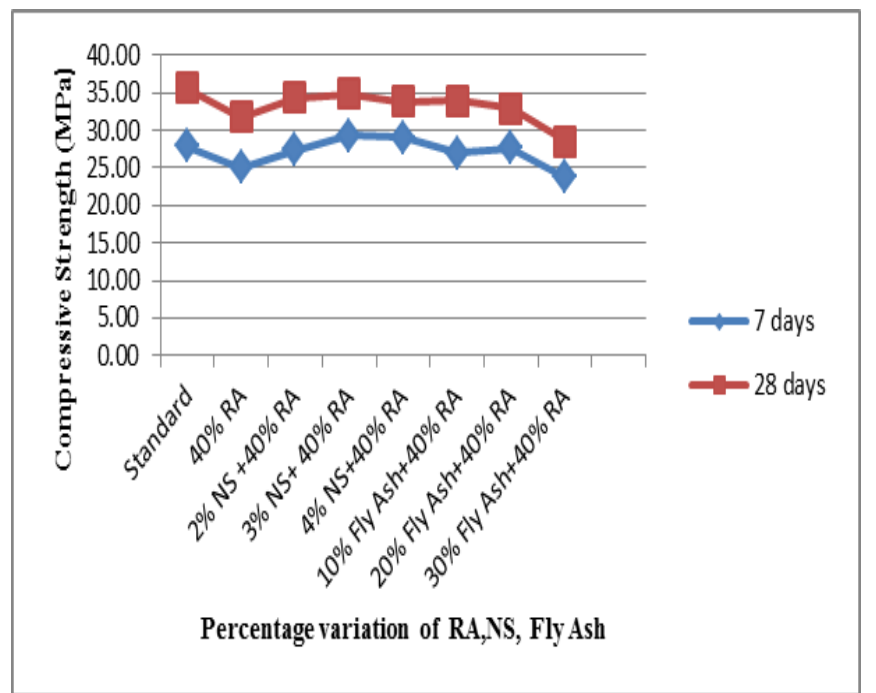

Chart-3: Compressive strength variation of concrete incorporating $40 \%$ of recycled aggregates with $2 \%, 3 \%, 4 \%$ of nanosilica and $10 \%, 20 \%, 30 \%$ of fly ash respectively.

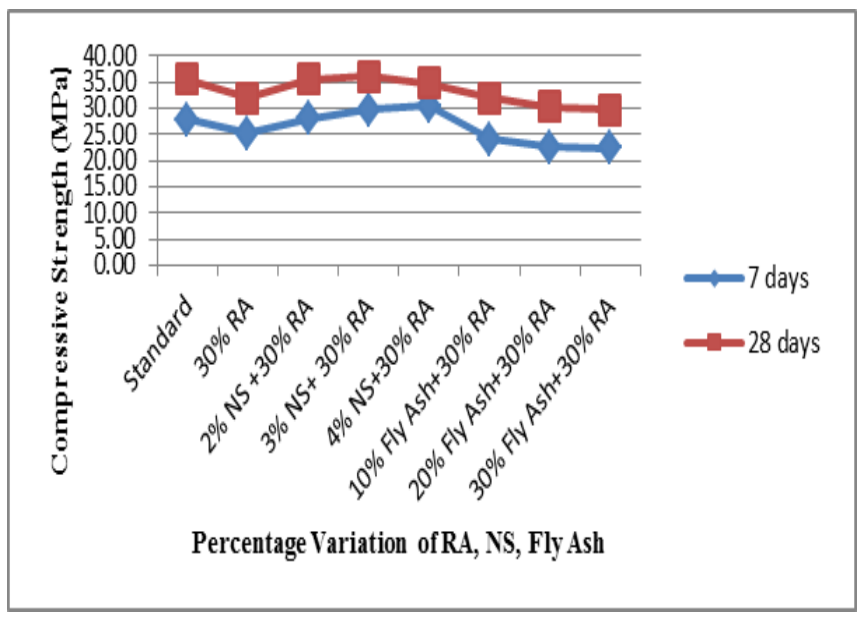

Chart-4: Compressive strength variation of concrete incorporating $30 \%$ of recycled aggregates with $2 \%, 3 \%, 4 \%$ of nanosilica and $10 \%, 20 \%, 30 \%$ of fly ash respectively. 


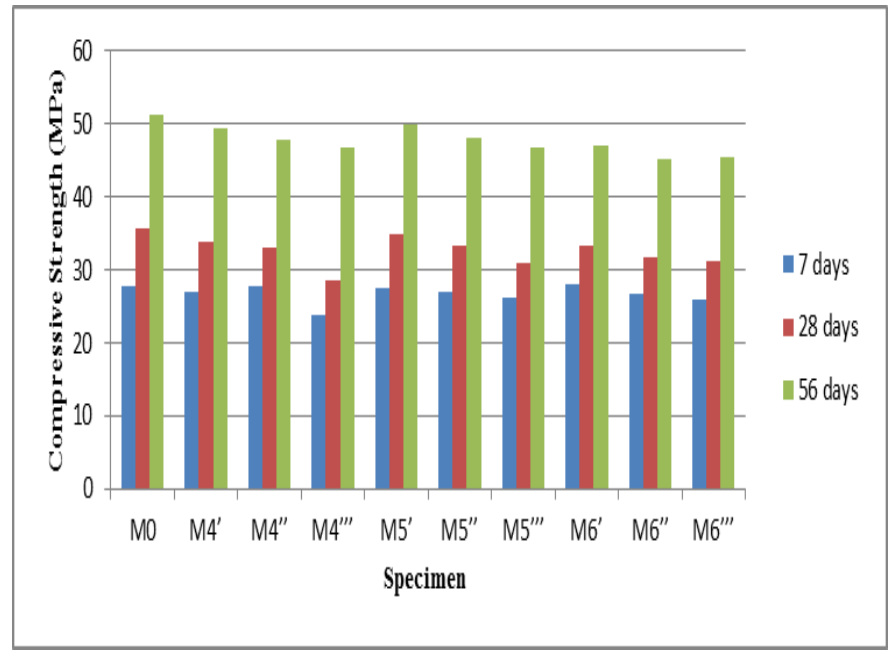

Chart-5: Compressive strength variation of concrete incorporating $30 \%$ of recycled aggregates with $2 \%, 3 \%, 4 \%$ of nanosilica in addition to $10 \%, 20 \%, 30 \%$ of fly ash.

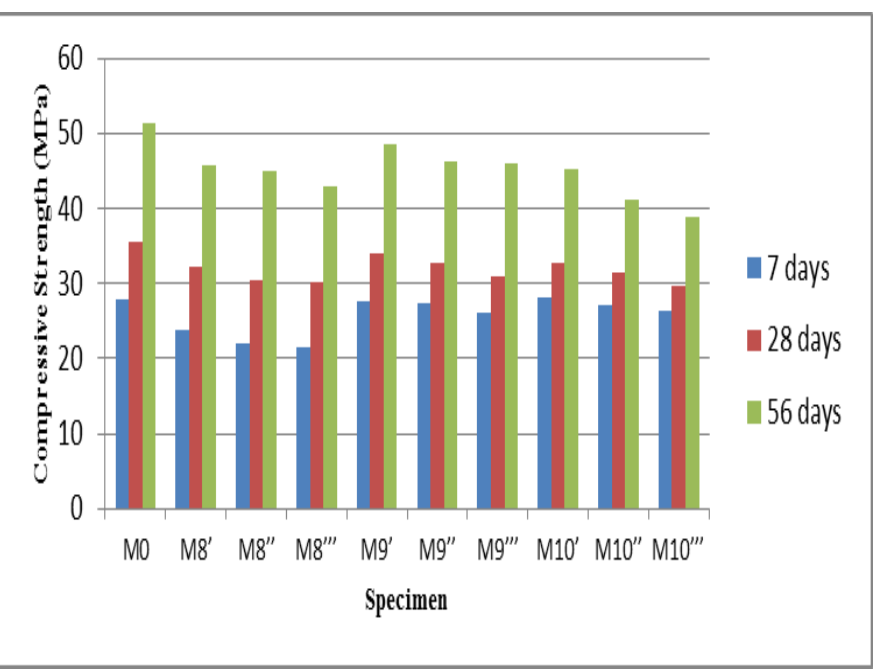

Chart-6: Compressive strength variation of concrete incorporating $30 \%$ of recycled aggregates with $2 \%, 3 \%, 4 \%$ of nanosilica in addition to $10 \%, 20 \%, 30 \%$ of fly ash.

It can be seen in chart 5 and chart 6 that with the use of fly ash in addition to nanosilica, the later age strength of recycled aggregate concrete with both $30 \%$ and $40 \%$ replacement was improved. Also, it was observed that 28 days and 56 days compressive strength of concrete with (30\% RA+3\% NS + 10\% Fly Ash) was comparable with the compressive strength of standard mix. However, the compressive strength was showing a decreasing pattern if the percentage of fly ash was increased for the same percentage of nanosilica.

\section{CONCLUSION}

The work presented in this paper investigates the effect of nanosilica and fly ash on the properties of recycled aggregate concrete. It was observed that compressive strength of concrete decreases with the use of recycled aggregates. With $20 \%$ replacement of aggregates, compressive strength was decreased by $8 \%$ and decrease was observed up to $19 \%$ when $50 \%$ of natural aggregates were replaced. Workability of concrete was decreased with the percentage increase of nanosilica and it was also found that there was minor decrease in workability with the percentage variation (20-50\%) of recycled aggregates. With the inclusion of nanosilica compressive strength of concrete showed improved results, particularly at early ages. However the early strength of the mix decreases marginally with addition of fly ash yet diminishes at later ages. Nanosilica helps in improving the compressive strength only if it is used within limit (2-3\%). When nanosilica was added $2 \%$ and $3 \%$ by weight of cement, the compressive strength of RAC showed improvement. But when percentage of nanosilica was increased i.e. by $4 \%$, the compressive strength decreased significantly. With addition of fly ash as $10 \%, 20 \%$ and $30 \%$ by weight of cement, both of the early age strength and later age strength obtained were decreased when compared with the compressive strength of standard mix. Also, it was observed that 28 days and 56 days compressive strength of concrete with $(30 \% \mathrm{RA}+3 \% \mathrm{NS}+$ $10 \%$ Fly Ash) was comparable with the compressive strength of standard mix. Hence fly ash in addition to nanosilica can be used to achieve the strength and workability requirements in recycled aggregate concrete.

\section{ACKNOWLEDGMENTS}

Authors would like to thank TEQIP-II for providing funds and PEC University Of Technology for infrastructure facilities.

\section{REFERENCES}

[1] Agamuthu, P. (2008) "Challenges in sustainable management of construction and demolition waste" Waste Manag Res, 26: 491

[2] Vyas C.M, Bhatt D.R (2013) "Use of Recycled Coarse Aggregate in Concrete" IJSR - international journal of scientific research Vol-2/issue -1, Jan 2013.

[3] Saurav (2012) “ Application of nanotechnology in building materials" International Journal of Engineering Research and Applications" Vol. 2, Issue5, September-October 2012, pp.1077-1082

[4] Bjornstrom J., Martinelli A., Matic A., Borjesson L. and I.Panas (2004) "Accelerating effects of colloidal nano-silica for beneficial calcium-silicatehydrate formation in cement", Chemical Physics Letters, 392, 242-248.

[5] Ji T. (2005) "Preliminary study on the water permeability and microstructure of concrete incorporating nano-SiO2", Cem. and Con. Res., 35, 1943-1947.

[6] Parekh D. N ,Modhera C. D (2011) “Assessment of recycled aggregate concrete" Journal of Engineering Research and Studies, Vol.II/ Issue I/January-March 2011/1-9.

[7] Babu G.R (2013) "Effect of nano-silica on properties of blended cement" International Journal of Computational Engineering Research/Vol, 03/Issue, $5 / 2013$. 
[8] Gaitero J.J., Campillo I. and Guerrero A. (2008)

"Reduction of the calcium leaching rate of cement paste by addition of silica nano particles" Cem. and Con. Res., 38, 1112-1118.

[9] ACI Committee 232: 1996. "Use of flyash in concrete".

[10] IS 2386 (Part1\&3):1963 "Methods of test for aggregates for concrete."

[11] IS 8112:2013 "OPC 43 grade -Specification."

[12] IS 516:1959 "Method of test for strength of concrete."

[13] IS 7320:1974 "Specification for concrete slump test appratus."

\section{BIOGRAPHIES}

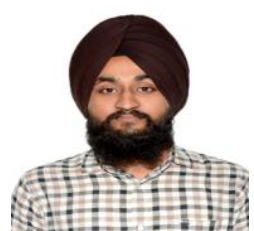

Prof. Arshdeep Singh, B.E (Civil), M.E. (Structures) is working as an Assistant Professor in Department of Civil Engineering, PEC University of Technology, Chandigarh. His area of active research includes the investigation on the effect of pozzolanic materials on concrete, advancement in concrete technology.

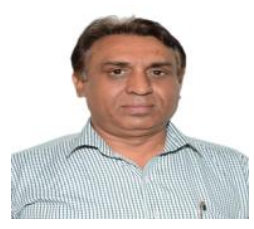

Prof. Roshan Lal, B.E (Civil), M.E. ( Civil Structures) is working as an Associate Professor in Department of Civil Engineering, PEC University of Technology, Chandigarh. His area of active research includes development and performance evaluation of special structural concretes, like SCC, HPFRC etc. Behavior of opening corner joints, Soil structure interaction.

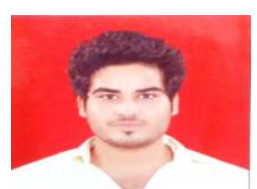

Pankaj Bavoria holds a B.Tech degree from DAVIET, Jalandhar. $\mathrm{He}$ is presently pursuing his M.E degree in structural engineering from PEC University of Technology, Chandigarh. His area of active research includes performance evaluation of recycled aggregate concrete and latest retrofitting techniques.

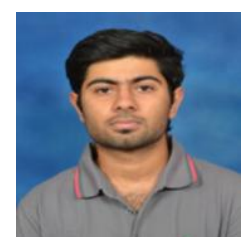

Abhinav Saklani holds a B.Tech degree from NIT, Hamirpur. He is presently pursuing his M.E degree in structural engineering from PEC University of Technology, Chandigarh. His area of interest in research includes performance evaluation of recycled aggregate concrete and soil structure interaction. 